\title{
PAUPERES AND THE FIRST CRUSADE: FROM THE PREACHING OF THE GRUSADE TO THE RISE OF THE VISIONARIES
}

Six months before the main armies of Europe set forth on the crusade under the leadership of princes, a more turbulent crowd embarked on the expedition under a variety of leaders: peasant visionaries, rogue magnates, mercenary commanders. This, the first wave of Christian armies making for Jerusalem, has become known as the Peasants' Crusade or People's Crusade, in contrast to the Princes' Crusade that followed them soon after. Most of narrative accounts of the activities of 'poor' of the First Crusade have tended to concentrate on the People's Crusade, after the defeat of which, at Civetot, 21 October 1096, their role is often depicted as being negligible, at best a burden to the betterarmed sections of the army.

In 1921, Frederick Duncalf published his study of the People's Crusade, helping shift a perception that the participants were separated from those of the Princes' Crusade by a wide social gulf and were something of a rabble. ${ }^{1}$ Duncalf pointed out that although the proportion of knights was indeed far less than for the later expeditions, they did include members of the nobility and displayed a high degree of organisation; especially the early contingents of the People's Crusade. The first group, who set off under the leadership of a knight from Poissy, Walter Sanzavohir, reached Constantinople, 20 July 1096, without significant mishap. ${ }^{2}$ Duncalf's article, primarily a narrative of events based upon the account in Albert of Aachen's Historia Iherosolimitana, concluded with an argument that the economic background to the appeal of the Crusade was one of prosperity rather than poverty. This, rather unconvincing conclusion, was somewhat tangential to the study and left unconsidered the question of the size and contribution of the survivors of the People's Crusade to the subsequent united army.

\footnotetext{
${ }^{1}$ F. Duncalf, 'The Peasants' Crusade,' American Historical Review, 26 (1920/1), pp. $440-453$.

${ }^{2}$ For Walter Sanzavohir see J. Riley-Smith, First Crusaders, p. 224.
} 
The key study of the role of the pauperes on the First Crusade, therefore, was that of Walter Porges published in $1946 .{ }^{3}$ At the core of his study was a belief that 'by the time the siege of Antioch was well underway, the non-combatants - the sick, crippled, and destitute, the women, children, and clergy - had captured and maintained an absolute and overwhelming majority. ${ }^{4}$ Although the article did not explore in full the consequence of this observation for the internal dynamics and tensions of the expedition, it did allow Porges to emphasise the importance of the role of the large numbers of clergy present in acting as the guardians of the common welfare, with responsibility above all for the poor. ${ }^{5} \mathrm{He}$ was particularly insightful with regard to events at Antioch immediately before battle between the besieged Christian forces and Kerbogha, atabeg of Mosul, 28 June 1098. Porges demonstrated that it was an alliance of the poorer Christians with the clergy, led by the papal legate, Bishop Adhémar of Le Puy, which, via visions and miracles, insisted the magnates lead the Christian forces into battle. ${ }^{6}$ On this issue Porges has not been superseded, despite the publication of a number of subsequent studies.

Colin Morris's detailed study of the finding of the Holy Lance (1984) added an important political dimension to the context of the discovery of that particular relic, namely the rivalry between the Norman and the Provençal contingents. ${ }^{7}$ His defence of the reliability of the account of Raymond of Aguilers was an important corrective to the view of the key historian for that event, whose credibility as a witness had been subject to challenge, particularly by J. H. Hill and L. L. Hill. ${ }^{8}$ Morris's observation that the outlook of the visionary Peter Bartholomew was shaped by three influences, Provençal, social, and clerical, was astute and while only briefly substantiated in the short article, is nevertheless borne out by a close examination of the content of all of the visions. ${ }^{9}$

\footnotetext{
${ }^{3}$ W. Porges, 'The Clergy, the Poor and the Non-Combatants on the First Crusade,' Speculum, 21 (1946), pp. 1-21.

${ }^{4}$ Ibid., p. 4.

${ }^{5}$ Ibid., p. 9.

${ }^{6}$ Ibid., p. 17. See below pp. 118-130.

${ }^{7}$ Colin Morris, 'Policy and Visions: the case of the Holy Lance at Antioch,' in War and Government in the Middle Ages: essays in honour of 7. O. Prestwich, ed. J. Gillingham and J. C. Holt (Woodbridge, 1984), pp. 33-45.

${ }^{8}$ See above pp. 28-9.

${ }^{9}$ Morris, 'Policy and Visions,' pp. 41-2. For Peter Bartholomew and an analysis of his visions see below pp. 121-147.
} 
Randall Rogers's subsequent study (1992) of the career of the most prominent visionary, Peter Bartholomew, in relation to the pauperes on the First Crusade was disappointing. ${ }^{10}$ Ironically, given the title of his work, Rogers did not include the perspective of the poor in the context of the discovery of the Holy Lance, except as a passive body in need of alms. ${ }^{11}$ Although he referenced Porges, Rogers failed to consider the earlier argument that behind the discovery of the Holy Lance was an active body of the poor, in alliance with the clergy, who through visions were articulating their own perspective and in particular their desire that the Christian forces should march out against Kerbogha before desertions by the magnates caused the expedition to disintegrate. Rogers's most valuable observation was a passing one, that 'the thoroughness with which the poor and pilgrims conducted their sackings were in part a consequence of the structure of the expedition and the economic impulses of crusading. Looting captured cities was a primary source of the income so essential for continued crusading. ${ }^{, 12}$ Not only is this statement true but the sources also allow considerable insight into the tension that existed within the First Crusade over the distribution of booty and its eventual resolution in favour of the poor in the form of a 'law of conquest." ${ }^{13}$ This 'law' did not allocate any captured goods or houses by right to the leaders of the army, but insisted that all booty be considered the inviolate property of its discoverer.

Rogers's discussion of the trial by ordeal of Peter Bartholomew fell short of that of Morris's brief account and was wrong in asserting that 'the poor exercised no independent political role subsequent to the fall of Peter Bartholomew. ${ }^{\prime 14}$ As discussed below, an alliance between the pauperes and the familiares of Count Raymond of Toulouse drove their prince on to Jerusalem, both from 'Arqa and from an attempt to stall at Tripoli. The lower social orders also asserted their property rights in advance of the storming of Jerusalem. Rogers stated in his conclusion

${ }^{10}$ R. Rogers, 'Peter Bartholemew and the Role of "The Poor" in the First Crusade', in Warriors and Churchmen in the High Middle Ages, ed. T. Reuter (London, 1992), pp. 109-122.

${ }^{11}$ Ibid., p. 115.

12 Ibid., p. 117.

${ }_{13}$ See below pp. 153-7; see also J. Prawer, The Latin Kingdom of Ferusalem (London, 1972), p. 65, and Crusader Institutions (Oxford, 1980), pp. 253-4; see also W. G. Zajac, 'Captured Property on the First Crusade,' The First Crusade, Origins and Impact, ed. J. Phillips (Manchester, 1997), pp. 153-180.

${ }_{14}$ Rogers, 'Peter Bartholomew', p. 121. 
that he considered the poor to have been a grouping on the crusade who 'tried to influence its course, ${ }^{15}$ but gave no evidence that he believed they actually did so, other than as auxiliaries in military activities.

A few modern longer works give some attention to the role of the poor during the First Crusade. ${ }^{16}$ Particular mention must be made of Norman Cohn's distinct perspective in The Pursuit of the Millennium where a short but vivid section attempts to place the violence of the poor in a context of wider medieval traditions of messianic fervour. ${ }^{17}$ This argument certainly carries some weight and draws attention to the fact that the official ideology of the First Crusade, as represented by Pope Urban II, might not have been the dominant one in the minds of the majority of the participants. Cohn's work is a useful corrective to those historians who simply take the hegemony of the senior princes for granted. A close study of the sources, however, particularly the work of the historian and eyewitness with the greatest interest in the thoughts of the poor, Raymond of Aguilers, does not reveal a feverish subterranean messianism among the poor but in fact a pragmatic adoption of ideas that would have been recognised as orthodox by the senior clergy. This is not to belittle the levels of insubordination evidenced by the poor, but simply to recognise that their actions were justified by reference to current religious practices, rather than violent eschatological language. Peter Bartholomew was no Jan Brockelson. ${ }^{18}$

Possibly the most significant study of the poor on the First Crusade is the least readily available. In the introduction to his unpublished $\mathrm{PhD}$. edition of Raymond of Aguilers's Historia Francorum qui ceperunt Iherusalem, John France undertook a considerable analysis of the political

${ }^{15}$ Rogers, 'Peter Bartholomew', p. 122.

${ }^{16}$ P. Alphandéry, L'Europe et L'idée de Croisades, 1 (Paris, 1954); N. Daniel, The Arabs and Mediaeval Europe, (London, 1979), pp. 120-135; J. Riley-Smith, The First Crusade and the Idea of Crusading (London, 1986) chapters 3 and 4; J. Flori, Pierre L'Ermite et la Première Croisade (Paris, 1999) chapters 17 and 18.

${ }_{17}$ N. Cohn, The Pursuit of the Millennium (London, 1957: Fifth edition 1972), pp. $61-70$.

${ }^{18}$ Jan Brockelson (John of Leyden), leader of an Anabaptist sect and insurrection in Münster (1534-5), see N. Cohn, In Pursuit of the Millenium, pp. 261-280. See also J. Riley-Smith, 'Christian Violence and the Crusades,' A. Sapir Abulafia, ed., Religious Violence between Christians and Jewes: Medieval Roots, Modern Perspectives (New York, 2002), pp. 3-20. On eschatology and the First Crusade see J. Rubenstein, 'How, or How Much, to Reevaluate Peter the Hermit', in S. J. Ridyard ed., The Medieval Crusade (Woodbridge, 2004), pp. 53-70. 
activities of the lower social orders. Some of this material has found its way into his later work. ${ }^{19}$ France added to Porges' view of the finding of the Holy Lance an assessment of the first vision of Peter Bartholomew that drew attention to those elements hostile to the princes. ${ }^{20} \mathrm{He}$ also saw the vision following the death of Adhémar, 1 August 1098, as one that 'revealed the anger, fears and desires of the people. ${ }^{21}$ The vision was correctly analysed as 'virtually a popular manifesto, but one with a strong Provençal bias. ${ }^{22}$ France also convincingly showed that there is a tension between the elements of the visions that articulate the needs of the poor and those that reserve a special position for Count Raymond of Toulouse. ${ }^{23}$ This is the key, in fact, to understanding the fall of Peter Bartholomew, immediately after he gave voice to a vision that stood too firmly in the camp of Count Raymond..$^{24}$ In providing an introduction to one particular author France was necessarily restrained from expanding these important insights into a full account of the career of Peter Bartholomew and the political role of the poor on the First Crusade.

A precondition for a thorough analysis of the role of the pauperes on the First Crusade has to be a close examination of the vocabulary of the major sources, in particular their complex use of a variety of terms for the lower social orders. The value of building a discussion on the results of the opening chapters of this book is that a tight focus can be obtained on the subject matter and it becomes possible to construct a fuller account of their role than has hitherto been achieved. But there is a further source of material that can be tapped, particularly with the setting forth of the expeditions and that is the substantial annalistic evidence. Typically, an annalist would only write a sentence or two about the crusade: 'in this year was the great expedition to Jerusalem', or some similar terse comment. But occasionally they would add an observation, which although brief, when compiled with the remarks by all the other annalists of the day, amounts to something of a treasure trove.

${ }^{19} \mathrm{~J}$. France, 'The crisis of the First Crusade: from the defeat of Kerbogha to the departure from Arqa', Byzantion, 40 (1970), pp. 276-308; J. France, Victory in the East (Cambridge, 1994), Chapter 10.

${ }^{20}$ RA XXX.

${ }^{21}$ RA XXXI.

${ }^{22}$ RA XXXII.

${ }^{23}$ RA XXXVIII.

${ }^{24}$ See below pp. $143-7$. 
In his article on the People's Crusade, Frederic Duncalf advanced the argument that the movement took place against 'favourable economic conditions rather than in famine and distress. ${ }^{25}$ Duncalf wished to reinforce his view that the expeditions of the People's Crusade were better organised than is generally given credit for. But while the main thrust of his argument was valid, this particular assertion needs amendment, for it gives the impression of an untroubled background to the preaching of the crusade. In fact, while the year 1096 might have been a relatively prosperous one, there is little doubt that the years immediately preceding the departure of people on the First Crusade were extremely difficult ones all over northern Europe.

An examination of the annalistic evidence makes clear that an acute upsurge of famine and plague took place at this time. Taking as the basis for a survey those annals published in the 38 volumes of the MGH Scriptores series, it can be seen that for the year 1092 there were three reports of a plague. Additionally, Bernold of St Blaisen (or Constance) recorded a famine for the whole of Saxony. ${ }^{26}$ For 1093, four annals report a plague, one a famine and one both. ${ }^{27}$ With respect to the entries for 1094, however, twenty annals record plague, two famine and three both. ${ }^{28}$ Furthermore Orderic Vitalis wrote of England that a drought that year gave rise to famine $;^{29}$ Bernold that a plague led to an increase in penitence and confession ${ }^{30}$ and Frutolf that it was a year of plague, hurricanes and floods. ${ }^{31}$ The upsurge of plague waned the following year, 1095, but it was still reported in seven annals, two of which recorded both plague and famine. ${ }^{32}$ Six annals reported famine for 1095, including Sigebert's, which added that as a result theft and arson against the rich had increased. ${ }^{33}$ Additionally the Annals of the

${ }^{25}$ F. Duncalf, 'The Peasants' Crusade', p. 452.

${ }^{26}$ MGH SS 17, 744; 30, 527; 2, 246. Bernold of St Blaisen (Constance), Chronicon,

I. S. Robinson ed., Die Chroniken Bertholds von Reichenau und Bernolds von Konstanz, MGH Scriptores rerum germanicorum nova series 14 (Hannover, 2003), p. 494.

${ }_{27}$ MGH SS: 3, 134; 6, 394; 9, 568; 17, 277; 17, 744; 24, 36.

${ }^{28}$ MGH SS: 3, 134; 4, 21; 4, 29; 5, 8; 5, 27; 6, 366; 8, 547; 10, 21; 10, 35; 10, 54; 10,$54 ; 10,253 ; 11,103 ; 16,16 ; 16,604 ; 16,726 ; 17,14 ; 17,294 ; 17,585 ; 17,744$; 21,$313 ; 27,521 ; 30,366$.

${ }^{29}$ OV $5,8$.

${ }^{30}$ Bernold of St. Blaisen, Chronicon, 515.

${ }^{31}$ Frutolf, Chronicon, Frutolfs und Ekkehards Chroniken und die Anonyme Kaiserchronik, ed. F.-J. Schmale and I. Schmale-Ott (Darmstadt, 1972), p. 106.

${ }_{32}$ Plague, MGH SS: 5, 8; 5, 1301; 10, $111 ; 13,648 ; 17,713$. Plague and famine, MGH SS, 8, 547; EA 123.

${ }_{33}$ MGH SS: 4, 29; 5, 27; 6, 367 (Sigebert); 14, 307; 19, 2; 23, 803. 
Four Masters reported that in Ireland up to a quarter of the population died of famine in $1095 .{ }^{34}$ Astonishingly, the only annals to record any natural disaster for 1096 were Annales Pragenses, to where the plague had evidently spread, and the Peterborough version of the Anglo-Saxon Chronicle, which reported the continuation of famine in England.$^{35} \mathrm{In}$ 1097, Ekkehard and Sigebert reported a famine and a plague respectively, but no other annal did so. In 1098 not one annal or chronicle reported a natural disaster.

These figures are not unproblematic, as some later annals incorporated earlier ones wholesale. ${ }^{36}$ So, for example, information from the entries in the Annals of Rosenfeld or the Annals of Würzburg has not been used here, as at this point both were copies of the Annals of Hildesheim. The picture created by this information is nevertheless distinct enough to draw firm conclusions. Famine and plague were present but localised in 1092 and 1093, only to rage widely during the years 1094 and 1095, before abruptly ending. The preaching of the crusade, from November 1095 and through 1096, took place then against a background of recent hardship and dislocation. Indeed, according to the brief entry in the Annals of St Blaisen for 1093, it was the plague that created the movement to Jerusalem. ${ }^{37}$

The annalistic evidence is supported by the crusading sources. Guibert of Nogent, an eyewitness, reported that the preaching of the crusade took place at a time of famine, which had the consequence that the inopum greges learned to feed often on the roots of wild plants. ${ }^{38}$ The famine reduced the wealth of all and was even threatening to the potentes. ${ }^{39}$ Guibert condemned those magnates who stored food for profit during a year of famine, writing that they considered the anguish of the starving vulgus to be of little importance. ${ }^{40}$

The Bavarian monk, Ekkehard, later abbot of Aura (1108-1125), wrote the relevant parts of his chronicle around 1105, having returned

\footnotetext{
34 Annals of the Four Masters, ed. J. O'Donovan (Dublin, 1856), p. 949.

${ }_{35}$ MGH SS 3, 120; Anon. various, The Anglo-Saxon Chronicles, ed. and trans. Michael Swanton (London, 2000), p. 233.

${ }^{36}$ For a discussion of this problem in general see F. Curschmann, Hungersnöte im Mittelatler (Leipzig, 1900), pp. 2-5. For the Annals of Nieder-Altaich, Regensburg, Freising, Salzburg and Passau in particular see W. Wattenbach ed., Deutschlands Geschichtsquellen im Mittelalter (Tübingen, 1948), I.3, 545-562.

${ }^{37}$ Annales Sancti Blasii, MGH SS 17, 277.

${ }^{38}$ GN 118.

${ }^{39}$ GN 118.

${ }^{40}$ GN 119.
} 


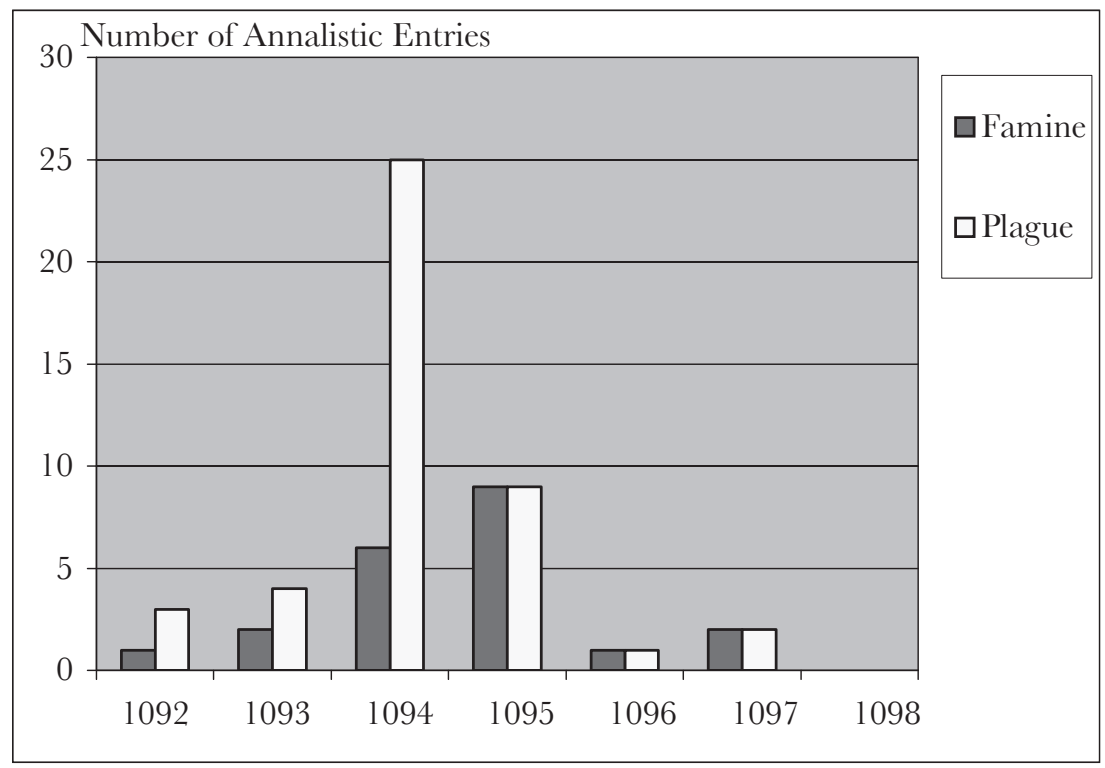

from Jerusalem where he had been a participant of the Crusade of 1101 and had come across a libellus of the First Crusade. ${ }^{41}$ He reported in his chronicle that it was easy to persuade the Francigenae to go to the orient because for some years previously Gallia had been afflicted by civil disorder (seditio), famine and an excessive mortality. ${ }^{42}$ Ekkehard vividly portrayed the appearance of a plague that caused limbs to wither through an invisible fire. It has plausibly been suggested that this was an outbreak of ergot poisoning among the rye crop, which would fit not only Ekkehard's description but also the pattern of a sharp outbreak of plague that disappeared by the time of the following harvest. ${ }^{43}$

In Robert the Monk's account of the preaching of the crusade by Pope Urban II at the council of Clermont, specific mention of the shortage of food in Christendom formed part of the appeal. ${ }^{44}$ If the

41 EA 148.

42 EA 140.

43 EA 140: Tactus quisquam igne invisibili quacumque corporis parte tam diu sensibili, immo incomparabili tormento etiam inremediabiliter ardebat, quosque vel spiritum cum cruciatu vel cruciatum cum ipso tacto membro amitteret. Testantur hoc hactenus nonnulli manibus vel pedibus hac pena truncati. For Ergot poisoning, high temperatures and gangrenous limbs, see M. McMullen and C. Stoltenow, Ergot (Fargo, 2002). See also J. Sumption, Pilgrimage (paperback edition: London, 2002), p. 75; J. Riley-Smith, The First Crusaders, p. 16.

44 RM 728. 
contrast between the poverty of the Western lands and lands flowing in milk and honey (Exodus 3:8) did indeed form part of the official message concerning the crusade addressed to the magnates, then it was all the more likely to have been an aspect of the unrecorded sermons of those who from their own initiative were preaching to more lowly orders. ${ }^{45}$

By the time for departure, however, especially for those leaving in the autumn of 1096, after the harvest, it was clear that yields for that year, on the continent, had recovered. Fulcher of Chartres, setting out in October 1096 with the contingent of Robert, duke of Normandy, wrote that there was a great abundance of grain and wine, so that there was no lack of bread for the travellers. ${ }^{46}$ Duncalf may have been right, therefore, to conjecture that the relatively successful march of the great crowds with Peter the Hermit, the itinerant preacher of the crusade, ${ }^{47}$ and Walter Sanzavohir to Constantinople implied ample supplies were present. But the supplies for these early crusading contingents, setting out before the autumn harvest, would either have been costly grain purchased from the great chest with innumerable gold and silver coins in which Peter the Hermit stored the contributions given to him, ${ }^{48}$ or else would have been livestock brought by the farmers.

Walter Sanzavohir left Cologne shortly after Easter, 12 April 1096, and Peter soon after, on or around 20 April 1096, both too early to benefit from any improved grain or legume harvests but perhaps able to find sufficient resources from a revival of livestock numbers and milk products. Whether or not the armies of Walter and Peter departed with adequate provisions, Duncalf certainly underestimated the agricultural hardship of 1094-1095 and thus the sense of dislocation that would have formed the background to the dissemination of the news of the crusade in the winter of 1095 and the spring of 1096.

There was clearly a massive response from the lower social orders to the idea of an expedition for God under the sign of the cross.

\footnotetext{
45 'Freelance' preaching, see J. Riley-Smith, The First Crusade, p. 31.

${ }^{46}$ FC I.vi.2 (154). Although famine persisted in England, The Anglo-Saxon Chronicles, ed. and trans. Michael Swanton (London, 2000), p. 233.

${ }^{47}$ For Peter the Hermit see J. Flori, Pierre l'Ermite et la Première Croisade (Paris, 1999). See also H. Hagenmeyer, Peter der Eremite (Leipzig, 1879); E. O. Blake and C. Morris. 'A hermit goes to war: Peter and the origins of the First Crusade,' Studies in Church History 22 (1984), pp. 79-107; M. D. Coupe, 'Peter the Hermit-A Reassessment,' Nottingham Medieval Studies 31 (1987), pp. 37-45.

${ }^{48}$ AA i.12 (24).
} 
Ekkehard was an eyewitness to the departure of people in Bavaria on the expedition and a key source for the People's Crusade. He observed of the very first contingents that along with a great many legions of equites were as many troops of pedites and crowds of ruricolae, women and children. ${ }^{49}$ Ekkehard also noted that some of the plebs as well as persons of higher rank admitted to having taken the vow through misfortune.$^{50}$ Furthermore, a great part of them proceeded laden with wives and children and all their household goods. ${ }^{51}$

Guibert of Nogent, an eyewitness to the departure of people from northern France to join with Peter the Hermit's contingent, observed exactly the same phenomena, that entire families of pauperes with carts full of their belongings joined the various contingents. He wrote that after the Council of Clermont: 'the spirit of the pauperes was inflamed with great desire for this [expedition] so that none of them made any account of their small wealth, or properly saw to the sale of homes, vineyards and fields. ${ }^{52}$ This passage is evidently a description of property-owning farmers, turning their fixed assets into ready wealth for the journey, even at much reduced prices. Guibert referred to the same body of people again, with additional detail: 'There you would have seen remarkable things, clearly most apt to be a joke; you saw certain pauperes, whose oxen had been fitted to a two-wheel cart and iron-clad as though they were horses, so as to carry in the cart a few possessions together with small children. ${ }^{53}$ Independently but with a similar turn of phrase, the northern French historian and the Bavarian chronicler found it noteworthy that peasant families participated in the crusade.

Guibert also provided clear evidence that people from the very lowest layers of the eleventh-century social spectrum responded to the idea of the crusade. He noted that the meanest most common men (homines extremae vulgaritatis) appropriated the idea of the expedition for themselves. ${ }^{54}$ Further evidence of the presence of those at the very bottom of society at the outset of the movement comes from a variety

49 EA 140.

50 EA 140.

51 EA 140.

52 GN 119:...pauperum animositas tantis ad hoc ipsum desideriis aspiravit ut eorum nemo de censuum parvitate tractaret, de domorum, vinearum et agrorum congruenti distractione curaret.

53 GN 120: Videres mirum quiddam, et plane joco aptissimum, pauperes videlicet quosdam bobus biroto applicitis, eisdemque in modum equorum ferratis, substantiolas cum parvulis in carruca convehere.

${ }^{54} \mathrm{GN} 300$. 
of sources. The Anglo-Saxon chronicler, writing in Peterborough, had very little to say about the Crusade, but he did think it noteworthy that countless people set out, with women and children (wifan and cildan). ${ }^{55}$ The near contemporary Annals of Augsburg say that along with warriors, bishops, abbots, monks, clerics and men of diverse professions, 'serfs and women' (coloni et mulieres) joined the movement. ${ }^{56}$ For 1096 Cosmas of Prague wrote that so many people departed for Jerusalem that there remained very few coloni in the urbes and villae of Germany and Eastern France. ${ }^{57}$

The appearance of the term coloni is important here. Christopher Tyerman's very impressive survey across the history of the crusades as to the various social groupings who took the cross expresses doubts when it comes to the question of serfs. Because, he argues, the serf had no freedom of action or choice, the serf could not participate in the movement independently of their master. Also their lack of resources meant that it does seem to have been the case that... serfs did not become crusaders. ${ }^{58}$ But this precludes the possibility that some serfs took advantage of the crusading message to leave their homes without permission from their lords, hoping to survive on charity and the distribution of captured booty.

That such a phenomena could happen in a crusading context is evident from the writings of Gerhoch, provost of Reichersberg, with regard to the departure of forces for the Second Crusade (1147). He noted that there was no lack of peasants and serfs on the expedition, 'the ploughs and services due to their lords having been abandoned without the knowledge or against the will of their lords. ${ }^{59}$ That this insubordinate participation took place in regard to the First Crusade is suggested by the mention of coloni in the Annals of Augsburg, the chronicle of Cosmas, and also the Monte Cassino Chronicle, which reported that so great a commotion of men and women took place in all the regions of the world wishing to join the Holy Journey that 'the father did not dare restrain the son, nor the wife the husband, and the dominus did not dare to restrain the servus.' Because of the fear and love of God,

\footnotetext{
55 Anon. various, The Anglo-Saxon Chronicles, p. 232.

${ }^{56}$ Annales Augustani, MGH SS, 3, 134.

${ }^{57}$ Cosmae Chron. Boemorum, MGH SS 11, 103.

${ }^{58}$ C. Tyerman, 'Who Went on the Crusades?' in B. Z. Kedar ed., The Horns of Hattīn (Jerusalem, 1992), pp. 14-26, here p. 24.

${ }_{59}$ Gerhoch, De Investigatione Antichristi Liber I MGH Historica Libelli de Lite Imperatorum et pontificum, Saeculis XI et XII conscripti, 3 (Hanover, 1897), p. 374.
} 
everyone was free to join the journey. ${ }^{60}$ Marwan Nader assumes servus here stands for a serf ${ }^{61}$ which is entirely possible, but even if its alternative meaning of 'servant' was meant by the compiler of the history, the point still stands, that the usual bonds of authority could be undermined by the appeal of the crusade.

The key figure in the mobilisation of the lower social orders on the First Crusade was Peter the Hermit. In an important passage concerning Peter the Hermit, the monk and historian Albert of Aachen, who had direct experience of the mobilisations for the crusade, described how through his powers of persuasion and his ability to inspire people to action, Peter mobilised all kinds of person, from senior clergy to the worst of criminals. ${ }^{62}$ Albert went to some length to indicate that Peter was preaching to all social layers and he drew attention to the preacher's success in appealing to women.

Guibert of Nogent, who wrote as an eyewitness to the preaching of Peter the Hermit, gave a very similar picture. He described Peter as moving through cities and towns surrounded by great multitudes and being given great donations. ${ }^{63}$ The fact that Peter the Hermit was described as travelling through towns and cities has been noted by $\mathrm{E}$. O. Blake and C. Morris as showing that his was an urban audience. ${ }^{64}$ The report of the donations of sizeable gifts suggests that Peter was obtaining some support from those with wealth in these urban centres. The evidence that Peter, nevertheless, had a particular appeal to the poor comes from Guibert's observation that the vulgus, slender in possessions and abundant in numbers, clung to the hermit. By contrast with the princes these vulgus made no careful preparations for the journey ${ }^{65}$ Furthermore Peter was very generous to the pauperes with the gifts he was given.$^{66}$ Guibert also reported that the vulgus, from love of novelty, tried to obtain hairs from the tail of the Hermit's donkey, as relics. ${ }^{67}$

${ }^{60}$ MC 174: Pater non audebat prohibere filium, nec uxor prohibere virum, et dominus non audebat prohibere servum.

${ }_{61}$ M. Nader, Burgesses and the burgess law in the Latin Kingdom of Jerusalem and Cyprus (1099-1325) (Aldershot, 2006), p. 20.

62 AA i.2 (2-4).

63 GN 121.

64 E. O. Blake and C. Morris, 'A hermit goes to war: Peter and the origins of the First Crusade', Studies in Church History 22, 1984, 79-107.

65 GN 121.

${ }^{66}$ GN 121.

${ }^{67}$ GN 121. 
In a passage that could well have been that of an eyewitness, Baldric of Dol also noted a similar eagerness of the poor to believe in miracles in response to news of the expedition. Baldric wrote that the gens plebia displayed a cross that certain 'foolish women' (mulierculae) claimed had been made in heaven. ${ }^{68}$

Once Peter and his following were underway the sources make it clear that the army was not a conventional one. Albert reported that the contingent of Walter Sanzavohir contained only eight knights; ${ }^{69}$ while that of Peter the Hermit was as innumerable as the sands of the sea and contained people who were foolish (insipientes) and rebellious (rebelles). ${ }^{70}$ Several times both Albert and Guibert described the contingent of Peter the Hermit as the vulgus. Albert again described Peter's following as 'rebellious' and also this time 'the incorrigible vulgus' when they set off from Nish, 4 July 1096, with their carts. ${ }^{71}$ That Albert was using the term vulgus in a pejorative manner is clear not only from the adjectives rebellis and incorrigibilis but also from his later account of a vision in which St Ambrose of Milan appeared. In this vision the saint explained that not everyone had departed on the expedition in the proper spirit, some of the primores and very many of the vulgus had set about this through lightness of mind (pro levitate animi). ${ }^{72}$

In a digression from his account of the People's Crusade Albert made his opinion clear, that many of these 'innumerable' people were using the glorious expedition inappropriately, particularly the women who boasted about the opportunities for pleasure offered by the expedition. ${ }^{73}$ Guibert, having observed that Peter the Hermit was unable to restrain the wayward behaviour of his followers in Hungary, described them as an indisciplinatum vulgus utpote mancipia et publica servitia. ${ }^{74}$ Again Guibert described the same immense army as an indocile vulgus who ran completely wild (debacchari) ${ }^{75}$ Robert the Monk wrote that because they did not have a wise princeps who ruled over them, they performed reprehensible deeds. ${ }^{76}$ When reporting that the Turkish forces annihilated

68 BD 17.

69 AA i.6 (8).

70 AA i.7 (12); i. 16 (32).

71 AA i. 12 (24).

72 AA iv.38 (307).

73 AA i.25 (49). For these women, see below Chapter Nine.

74 GN 123.

75 GN 121.

76 RM 732. 
the People's Crusade at Civetot, Robert wrote that 'there the multitudo overcame rashness, not rashness the multitudo. ${ }^{77}$ Guibert of Nogent applied the term turba to the People's Crusade on three occasions. ${ }^{78}$

This kind of language was not used for the forces marshalled under the leadership of the senior princes. In part it expresses a sense of offended propriety by monastic authors that a section of the population should display an independence of spirit in choosing to join the crusade outside the direction of a superior. But it also reflects a genuine inchoateness in these armies, arising from the fact that non-combatants and poorly armed farmers with no military experience formed such a large part of their body. In the course of his account Albert used the device of an imagined letter from Qilij Arslan, sultan of Rūm, to Kerbogha, atabeg of Mosul, after the destruction of the army of Peter the Hermit. It provides a summation of how Albert supposed an outsider would see the forces of the People's Crusade, namely: a pitiful band, mostly footsoldiers and a useless vulgus of women, all being wearied from the long journey, with only 500 knights. $^{79}$

Thousands more gathered together in armies intending to join with Peter the Hermit. One of these was the contingent led by the priest Godshalk, described by Albert of Aachen as having been inflamed by the preaching of Peter, ${ }^{80}$ and by Ekkehard as a false servant of God. ${ }^{81}$ A priest, Folkmar, led another and a third was led by Count Emicho of Flonheim. ${ }^{82}$ Parts of Emicho's army were described by Albert of as being stultus and having a 'frenzied levitas' for claiming to follow the lead of a goose and a she-goat..$^{83}$ These expeditions disintegrated without contributing to the Christian forces in Asia Minor (with the exception of a group of knights from the company of Emicho, who later joined with Hugh the Great), although not before terrorising the Jewish communities of the Rhineland. ${ }^{84}$

77 RM 735: Ibi multitudo audaciam, non audacia multitudinem superavit.

78 GN 98, 124, 127.

79 AA iv.6 (254).

80 AA i.23 (44).

81 EA 144. For Godschalk see J. Riley-Smith, First Crusaders, p. 209.

${ }^{82}$ For Folkmar see J. Riley-Smith, First Crusaders, p. 205, for Emicho of Flonheim see AA 51 n. 66.

83 AA i.30 (58).

84 See N. Golb, 'New Light on the Persecution of French Jews at the Time of the First Crusade,' Proceedings of the American Academy for Fewish Research, Vol. 34. (1966), pp. 1-63. R. Chazan, European Fewry and the First Crusade, (Berkeley, 1987). See also J. Riley-Smith, The First Crusade, pp. 50-7; J. Riley-Smith, 'The First Crusade and the 
The reunited army of Peter the Hermit and Walter Sanzavohir at Givetot, 11 August-21 October 1096, was a vast one with a disproportionate body of people from the lower social orders. Can an estimate be made of its numbers? Among the wilder stylistic and biblical figures given by the sources, Jean Flori, in his discussion of the subject, draws attention to two plausible figures. ${ }^{85}$ Raymond of Aguilers, who would have obtained the information only after his arrival at Constantinople the following April, wrote that 60,000 followers of Peter the Hermit were lost when the Christian forces suffered their catastrophic defeat at the battle of Civetot. ${ }^{86}$ Albert of Aachen wrote that Walter Sanzavohir led out 500 knights and 25,000 footsoldiers to that battle. The two figures are not incompatible as Albert also reported that 'innumerable' non-combatants remained in the camp. ${ }^{87}$ An impressionistic but vivid indication of the large numbers of people who had been killed in and around the camp at Civetot was that given by Fulcher of Chartres, who shed tears at the great number of severed heads and bones he saw in the fields nine months after the battle of Civetot. ${ }^{88}$

With the destruction of the armies of Peter the Hermit and Walter Sanzavohir the unspoken assumption of many twentieth century narrative histories of the First Crusade is that the impact of the lower social orders on subsequent events was negligible. It will be demonstrated that this was not the case. A sizeable remnant of the forces of the People's Crusade joined with the princes, not only the fragment remaining with Peter at Constantinople, but also those who had been taken to Nicea and Antioch as prisoners.

The Gesta Francorum has quite a detailed account of the destruction of the united army of the People's Crusade. Although the anonymous author did not arrive in the region until April 1097, the details seem to be convincingly authentic and agree with the well-informed account of Albert of Aachen. Albert wrote that three thousand pilgrims sought

Persecution of the Jews', Studies in Church History, 21 (1984), pp. 51-72; R. Chazan, In the year 1096: The First Crusade and the Feres (Philadelphia, 1996); A. Havercamp ed., Juden und Christen zur Zeit der Krezzüge (Sigmaringen, 1999); D. Malkiel, 'Destruction and Conversion: Intention and Reaction, Crusaders and Jews in 1096', Jewish History 15 (2001), pp. 257-80.

${ }^{85}$ J. Flori, Pierre L'Ermite, pp. 455-7.

${ }^{86}$ RA 63.

${ }^{87}$ AA i.19 (38).

${ }^{88}$ FC I.ix.5 (180). 
to defend themselves in a ruined fortress and that the Turks sought to force them to surrender. ${ }^{89}$ The Gesta Francorum reported these Christians as having been captured alive and distributed through all the neighbouring lands. ${ }^{90}$ Raymond of Aguilers made a similar observation. ${ }^{91}$ Guibert described how the defeated forces faced dismal servitude at the hands of cruel lords. ${ }^{92}$ It is clear that the Turks sought for captives after defeating the military forces of the People's Crusade. ${ }^{93}$ This explains the observation of Albert of Aachen, that on the surrender of Nicea, 19 June 1097, many of the Christian prisoners were returned, including a nun from the convent of St Maria in Oeren (Trier) who was described as having been captured at the time of the reduction of Peter the Hermit's forces. ${ }^{94}$ Given the nature of the market for slaves, it is likely that these released prisoners were female or young noncombatants. A large slave market was held at Antioch and after the crusade had captured the 'Iron Bridge', a fortress on the bridge that controlled the crossing of the Orontes to the north of the city, they discovered 'very many of Peter's army' who had been imprisoned all around the region of Antioch. ${ }^{95}$

If the regrouped remnants of the People's Crusade under Peter the Hermit, together with those released from captivity from Nicea and the regions of Antioch, formed a part of the pauperes that now marched with the united expedition, there were even greater numbers of pauperes present who had set off with the princes. The sources indicate that a body of pauperes accompanied each of the main contingents.

Raymond of Aguilers wrote of how in the winter of 1096 the stragglers of the Provençal contingent became the targets of the inhabitants of Dalmatia who slaughtered old women, the pauperes and the sick. ${ }^{96}$ Fulcher reported with compassion that very many of the plebs of the contingent of Duke Robert of Normandy and Count Stephen of Blois drowned in a sudden surge of the current as they tried to cross the Skumbi (Genusus) river on the Via Egnatia between Durazzo and Constantinople, April 1097.97

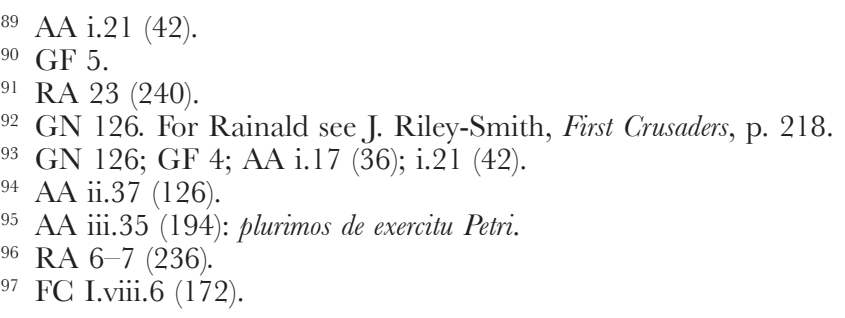

${ }^{97}$ FC I.viii.6 (172). 
The author of the Gesta Francorum noted that the offer by the Byzantine emperor, Alexios I Comnenus, to Duke Godfrey that encouraged the leader of the Lotharingian contingent to cross the Arm of Saint George included the promise that the emperor would give alms to the pauperes of the Lotharingian forces. ${ }^{98}$

The anonymous author of the Gesta Francorum had a limited vocabulary of social order and elsewhere rarely commented on the pauperes. The Benedictine monks of Northern France who used his work as their fons formalis, however, added more social detail, including observations made with regard to the lower social orders. Robert the Monk, for example, wrote that when Bohemond gathered forces to him from Apulia for the journey to the Holy Sepulchre, it was not only optimates but people from across all social layers came to him, the mediocres and the potentes, the old and the young, servi and domini. ${ }^{99}$ Guibert of Nogent indicated that he also considered there to have been a sizeable presence of pauperes in the contingent of Bohemond. According to the Gesta Francorum, as a result of a shortage of markets in Greece, 5 April 1097, Bohemond left the route that he had agreed with the Byzantine authorities to march along and entered a valley abundantly supplied with different kinds of food. ${ }^{100}$ In Guibert's recounting of this incident he added that the decision was taken in order to provide for the pauperes. ${ }^{101}$

Baldric took the opportunity provided by the same incident to compose a speech for Bohemond that expressed one of Baldric's major themes: that the Christian forces on the expedition displayed social harmony. He had Bohemond urge the proceres and opulentiores to attend to the pedites and use their resources as alms for the pauperes. ${ }^{102}$ The speech is fanciful but it indicates that Baldric considered there to have been a sizeable body of pauperes attached to Bohemond's forces. This is also evident in Baldric's report that when the Norman prince Tancred wished to avoid taking an oath to Alexios, together with Richard of the Principate, count of Salerno, he hid among the commoners. ${ }^{103}$ Albert of Aachen gave a summary of this issue with regard to all the contingents led by senior princes when he wrote that it is not to be

\footnotetext{
98 GF 7.

99 RM 742.

$100 \mathrm{GF} 11$.

101 GN 141.

102 BD 22-3.

103 BD 25.
} 
doubted that together with so many captains of the first rank were not a few sequaces and inferiores: servi, ancillae; married and unmarried maids; men and women of every ordo.'104

The combined grouping of pauperes formed a significant body within the expedition. There were enough young children present for Guibert of Nogent later to learn that they formed themselves into an army and elected princes of their own, named after the adult leaders of the army. ${ }^{105}$ Albert of Aachen noted the presence of the poor during the siege of Nicea, April 1097-19 June 1097. A large amount of alms was distributed to the egeni at the funeral of Guy of Possesse and Walo of Lille. ${ }^{106}$ Here the 'destitute' were simply the conventional body to whom charity extended. Albert recorded, however, a more active role for the lower social orders at the siege when he described a certain Turkish soldier as flinging rocky stones with both hands into the middle of the vulgus. ${ }^{107}$

Towards the end of May 1097, during the siege, Albert wrote about the 'whole of the Christian army, parvi et magni' assembling as one, so that innumerable numbers of the vulgus both on horse and on foot, could go to Givetot where there were ships that needed to be hauled overland to the lake at Nicea. ${ }^{108}$ It is notable that for an undertaking that required the labour of thousands of people, the princes could not simply order the commoners, but had to win their agreement through the mechanism of a decision-making council in which parvi participated.

Lacking one overall leader the expedition had decision-making bodies of several types. Each contingent held meetings of its own people, and, separately, its own proceres. Collectively, a council of the senior princes usually made the major decisions of the crusade, but sometimes, as in this instance, it seems to have been the case that a much broader assembly of people was called together.

After the siege of Nicea, very many of the sources noted that the Byzantine emperor, Alexios I Comnenus, gave a distribution of alms to the pauperes. This was one of the few occasions that the pauperes came to the attention of the author of the Gesta Francorum. In summing up

104 AA ii.24 (100): Nec dubitandum est cum tot capitaneis primis, non paucos affuisse sequaces et inferiores, servos, ancillas, nuptas et innuptas, cuiusque ordinis, viros ac mulieres.

105 GN 309.

106 AA ii.29 (112).

107 AA ii.33 (118).

108 AA ii.32, (115): Universi de exercitu, parvi et magni. 
the siege and the sense of frustration that the sacrifices of the crusading forces had not been properly rewarded, he pointed out that many of the pauperrimae gentes starved to death. ${ }^{109}$ Immediately afterwards he nevertheless noted that, exceedingly pleased with the fall of Nicea, Alexios 'ordered alms to be distributed bountifully to nostri pauperes.' 110 Karl Leyser wrote that those who received alms from the emperor were "our "poor", i.e. the mass of the pedites."111 The conflation of pauper with pedes here is unhelpful. It does not seem to be the case that the alms distributed by Alexios were given to footsoldiers, since there was considerable resentment after the siege of Nicea that those who actively took part in it were left without reward. ${ }^{112}$ It seems inherently more likely that the alms were given to the most impoverished among the Christian forces, the non-combatant poor.

Robert the Monk simply repeated the information that after fall of Nicea, Alexios instructed a payout of lavish alms to the pauperes. ${ }^{113}$ Baldric of Dol, however, not only reported that Alexios made a large donation to the pauperes of the Christian forces, ${ }^{114}$ but he elaborated on the Gesta Francorum's implicit criticism that the crusading army had not been properly rewarded. Baldric wrote that the Christian army regretted the long siege and that if the property of their enemies had been made public, the poverty of the egeni could have been alleviated. ${ }^{115}$ Raymond of Aguilers added a further small detail to this incident, when he reported that Alexios promised that when Nicea was captured he would found there a Latin monastery and hospice for pauperes Francorum. ${ }^{116}$ The sources for the First Crusade at the siege of Nicea all therefore indicate an awareness of the Christian pauperes and also that they were suffering hardship. Only Albert of Aachen at this point described them as an active body of persons, rather than simply those in need of charity. This was a perspective that did not begin to change in the early crusading histories until they came to report the events following the fall of Antioch.

109 GF 17.

110 GF 18: Iussit maximas elemosinas erogari nostris pauperibus.

111 K. Leyser, Communications and Power, p. 88.

112 GN 153. WT 3.12 (211).

113 RM 758.

114 BD 30.

115 BD 30.

116 RA 22 (240). 
The Christian forces arrived at Antioch on 21 October 1097. It was not to fall to them until 3 June 1098. The various accounts of the siege of the city all included a recognition that when winter came, famine struck the besieging forces and it was the poor among them that suffered the most. Albert of Aachen described how death from famine was great among the humilis populus. ${ }^{117} \mathrm{He}$ also reported that the great famine caused an inestimable mortality of the humilis plebs and the whole army began to diminish. ${ }^{18}$

In writing about the extreme hardship of January 1098, Fulcher described a situation where 'both divites and pauperes, were desolate either from famine or the daily slaughter. ${ }^{\prime 19}$ Not that the suffering affected both groups equally, Fulcher also observed that 'the poorer people (pauperiores) ate even the hides of the beasts and seeds of grain found in manure. ${ }^{\prime 20}$ Because of the hardship of the siege it was the pauperes who were first to leave in search of sustenance from nearby towns they were subsequently followed by the locupletes. ${ }^{121}$ Raymond of Aguilers also reported that as a result of the famine experienced by the expedition as it besieged Antioch in the early days of 1098, the pauperes began to leave and also many divites fearing paupertas. ${ }^{122}$

In another example arising from the same period of the expedition the pauperes were described as fearing to cross the Orontes to find fodder, giving an insight into at least one of their activities. ${ }^{123}$ That the 'poor' included farmers with oxen was indicated by Raymond of Aguilers in his report that during the winter of 1097 sorties from the city of Antioch against their besiegers killed squires and rustici who were pasturing horses and oxen beyond the river. ${ }^{124}$

The anonymous author of the Gesta Francorum wrote that because of the famine, around February 1098, the gens minuta et pauperrima, fled to Cyprus, Rum and into the mountains. ${ }^{125}$ Guibert's version of the same information was that the vulgus, having been eaten up by all kinds

\footnotetext{
117 AA iii.50 (216).

118 AA iii.52 (220).

119 FC I.xv. 15 (223): Desolati tam fame quam cotidiana occisione, tam divites quam pauperes.

${ }^{120}$ FG I, xvi.2 (226): Pauperiores etiam bestiarum coria et annonae grana in stercoribus reperta comedebant.

121 FC I.xvi.6 (228).

122 RA 46 (245).

123 RA 50 (246).

124 RA 36 (243).

125 GF 35.
} 
of poverty, wandered through various provinces. ${ }^{126}$ Both Guibert and Robert the Monk made the similar observation that it was no wonder those of poor or feeble spirits faltered at this time when even the princes wavered. ${ }^{127}$ The anonymous mentioned the poor again, this time in attributing a speech to Bohemond shortly before the city fell, in which the Norman prince drew attention to the great poverty that everyone was suffering, maiores siue minores. ${ }^{128}$ Baldric of Dol in his version of the same speech had Bohemond refer to the suffering both of the plebeii homines and those who were illustris sanguinis stemmata. ${ }^{129}$

By and large the depiction of the suffering of the poorest of the Christian army in the winter of 1097 was a passive one. In the main they were considered to be the undeserved victims of hardship, eliciting the sympathy of the historians. One grouping of the pauperes who were not considered in such a light were the women who had come on the expedition. A purge of the camp in the first few days of 1098 saw many women driven off to nearby towns and a reinforced effort at social control, which included a clampdown on adultery. This event is discussed in context in Chapter Nine. ${ }^{130}$

There are hints though that a degree of social tension over the direction of the crusade might have arisen at this time. Robert the Monk's version of these events was that as the multitudo was being pressed by so many hardships, there was no lack of murmuring voices. ${ }^{131}$ In the vocabulary of a Benedictine monk the verb murmurare has strong overtones of rebellion, as 'murmuring' was considered a major infringement of the well known Rule of St Benedict. ${ }^{132}$

A similar note of social dissension occurred in the appearance of a distinct band of poor crusaders at this time, the tafurs. In a famous passage Guibert of Nogent described a body of the poor as having formed a company who revelled in their poverty. They marched barefoot, had no arms or money, but nevertheless they were ferocious. Their leader had fallen from his status as a man of high birth, to that of a footsoldier. He offered to put himself at the head of this band

${ }^{126}$ GN 185.

${ }^{127}$ RM 781; GN 175.

${ }^{128}$ GF 44.

${ }^{129}$ BD 53-4.

${ }^{130}$ See below pp. 281-2.

${ }^{131}$ RM 777.

${ }_{132}$ Benedicta Regula, 34, 6: Ante omnia, ne murmurationis malum pro qualicumque causa in aliquo qualicumque verbo vel significatione appareat. 
and was declared to be their king. ${ }^{133}$ It is hard to tell how much of this information is authentic as it is likely that Guibert would have been exposed to material from two vernacular epics whose comic and shocking portrayal of the behaviour of the tafurs was primarily included for the sake of entertainment and thus liable to have been considerably exaggerated. Although the specific historical information given in the Chanson d'Antioche is unreliable, and that in the Chanson de férusalem almost entirely without value, echoes of the genuine experiences of the crusaders can be found in them. ${ }^{134}$

The tafurs were portrayed in these epics as resorting to cannibalism and being so ferocious that even the Christian princes did not dare to approach them. ${ }^{135}$ This, rather than the reported speeches of King Tafur, is the kind of material that is most likely to reflect some genuine aspect of the behaviour of the tafurs: certainly acts of cannibalism are well documented by the sources. At the very least it indicates that a large body of the poor, unattached to any of the princes, organised themselves and become a noteworthy part of the expedition. More reliably, Albert of Aachen described other bands of starving people from the Christian army, some two or three hundred strong, searching for food with an agreement to divide everything they found or captured equally. ${ }^{136}$

While there is a more than a hint of insubordination in this banding together of the poor, in general it is clear that the princes of the expedition did consider it their responsibility to assist those in need in this time of famine and harassment from the garrison of Antioch. Albert of Aachen reported that Duke Godfrey agreed to lead an expedition for the sake of the adtenuata plebs. ${ }^{137} \mathrm{He}$ also described how Count Hugh of Saint-Pol urged that his son Engelrand should free and avenge his pauperes and fellow Christians from the attacks and slaughter of the Turks. ${ }^{138}$

133 GN 310.

134 La Chanson d'Antioche ed. S. Duparc-Quioc, 2 (Paris, 1977); La Chanson de férusalem, ed. Nigel R. Thorpe, (Tuscaloosa, 1991). For references to secondary literature concerned with the tafurs see above p. 82 n. 171.

${ }^{135}$ L. A. M. Sumberg, 'The Tafurs and the First Crusade', Mediaeval Studies 21, (1951), pp. 224-246, passim. CA 4050-4118.

${ }^{136}$ AA iii.52 (22).

137 AA iii.58 (228).

138 AA 265. For Hugh II, count of Saint-Pol A. V. Murray, The Crusader Kingdom of Ferusalem (Oxford, 2000), p. 213. For Engelrand of Saint-Pol see A. V. Murray, The Crusader Kingdom, pp. 192-3. 
Shortly before Christmas 1097 the hardship experienced by the Christian forces before Antioch resulted in a decision to send out a detachment in search of supplies. Baldric of Dol's account of this period follows the Gesta Francorum very closely. After he reported the announcement of the decision to send out foragers, however, Baldric added the extra observation that, 'naturally, with paternal affection, the maiores were giving protection to the minores. ${ }^{\text {"139 }}$ Baldric was consistently anxious in his work to emphasise that social harmony existed on the crusade. Perhaps a more reliable indicator of the historical reality was Guibert's description of the building of the castle Malregard, soon after 17 November 1097. Guibert was well aware that he lived in a society in which the rich preyed upon the poor, so although he was no nearer to events than Baldric, his observation that both the egena manus and the maiores worked equally hard to build the castle looks less like a didactic insertion. ${ }^{140}$

Antioch fell on 3 June 1097. According to the account of Fulcher of Chartres, who was in Edessa at the time, the scramble for booty in the city led to the first open social breach between rich and poor on the First Crusade. While the plebs seized everything they could in a disorderly manner, the milites continued to seek out and kill Turks. ${ }^{141}$ The question of the distribution of captured goods was an acute one. As early as at the siege of Nicea the right of the princes to dispose of captured property was being challenged; not initially by the poorest of the pauperes, who had been given a gift of cash by Emperor Alexios I Comnenus, but those of the middle rank, who felt that they had done all the work but been deprived of their just reward. ${ }^{142}$

In the early twelfth century poetic reworking of the Gesta Francorum by Gilo, a Cluniac monk from Toucy in Auxerre who subsequently became cardinal-bishop of Tusculum, ${ }^{143}$ there is more than a suggestion that during the course of the siege of Antioch the knights had sought to retain to themselves all the plunder they had obtained. On 5 April 1098, a castle was built opposite the Gate of St George and for the sum of four hundred marks Tancred took charge of it. Of this Gilo

\footnotetext{
139 BD 42: Affectu quippe paterno maiores minoribus patrocinabantur.

140 GN 172.

${ }^{141}$ FG I.xvii.7 (234-5).

${ }^{142}$ GN 153, WT 3.12 (211).

${ }^{143}$ GP xviii-iv. For Gilo see GP xix-xxii and R. Hüls, Kardinäle, Klerus and Kirchen Roms (Biblothek des Deutschen Historischen Instuits in Rom 48: Tübingen, 1977), pp. $142-3$.
} 
stated: 'Here also a certain castle was renovated and an old rampart was repaired where the iuvenes could keep their plunder. ${ }^{144}$ At some point during the course of the expedition a law (ius) had become established, such that ownership of booty was retained by the first person to lay hands on it, or leave their mark on it, no matter how lowly their status. The fall of Antioch was the first opportunity for the poor to obtain plunder ahead of knights, such as those at Tancred's castle, and they seem to have taken it without reprisal.

Within three days of Antioch having fallen to the Christian forces, on 6 June 1098, a great army led by Kerbogha, atabeg of Mosul, arrived to trap the Christians in the city. A Turkish garrison still held the citadel, putting the crusaders under pressure from within the walls. This was the period of greatest crisis for the expedition, where it seemed to be on the verge of disintegration right up to the moment when the Christian army came out to battle and inflicted a decisive defeat on Kerbogha's forces.

The vulgus were the subject of sympathetic commentary by Albert of Aachen in this critical period. He reported that on the day of the Christian breakthrough into Antioch, the Turkish forces in the citadel savaged with arrows very many incautious Christians of the vulgus, men and women. ${ }^{145}$ The subsequent famine among the Christians in the city was so severe that the inactive and modicum vulgus were reduced to attempting to obtain sustenance from the leather of their shoes. ${ }^{146}$ Guibert of Nogent similarly wrote that the extraordinary lack of food particularly weakened the courage of everyone of poorer means (pauperior). ${ }^{147} \mathrm{He}$ continued by reporting that while the wealthy ate the meat of animals, the poor ate the skins that had been boiled for a long time. ${ }^{148}$

The real danger for the poor, however, was that knights were lowering themselves by ropes from the walls of Antioch in order to escape the crisis and if this were to continue the Christian forces would melt away to the point that battle against Kerbogha was impossible. Tatikios, the envoy of the Byzantine Emperor, made his excuses and

144 GP p. 123: Hic quoque, quo iuuenes predam cepere, nouatur Quoddam castellum uallumque uetus reparatur.

145 AA iv.23 (282).

146 AA iv.34 (300).

147 GN 225.

148 GN 225. 
abandoned the siege in February 1098. ${ }^{149}$ Just before Antioch had been captured Stephen of Blois had departed, giving rise to a great deal of bitterness at his conduct. ${ }^{150}$ Now, while besieged by Kerbogha, many more knights were stealing away from the Christian army. The Gesta Francorum recorded that William of Grandmesnil, Aubrey his brother, Guy Trousseau of Montlhéry, Lambert the Poor and many others let themselves down from the wall secretly during the night and fled on foot towards the sea. ${ }^{151}$ Peter Tudebode added the name of Ivo of Grandmesnil, sheriff of Leicester, to the list and reported that many of the maiores wished to flee from the city by night. ${ }^{152}$

Raymond of Aguilers reported that the people believed there were few principes who did not, in fact, wish to flee to the port. But for the fact that the Bishop Adhémar of Le Puy, the papal legate, and Bohemond had closed the gates to the city 'very few would have remained.'153 Raymond reported that many people did leave, both clergy and laity. ${ }^{154}$ Fulcher similarly reported that many people wished to descend by ropes at night and escape. ${ }^{155}$

According to Albert of Aachen, when the news that even illustrious proceres had fled the city, very many people considered making a similar escape. ${ }^{156}$ Worse, there were princes so terrified of the plight of the crusade, that, unknown to the humilis vulgus, they had formed a conspiracy to leave the city together. ${ }^{157}$ Robert the Monk was apologetic for reporting such desertions and explained that he did so only so that it should be learned how great a need existed in the camp that even the divites were compelled to flee and to break their oaths (perjurare). ${ }^{158}$ Guibert, familiar with some of the returned knights, was more scathing and added the information that Guy Trousseau of Montlhéry was the ringleader of the party of deserters listed in the Gesta Francorum. ${ }^{159}$ The

149 GF 34.

150 GF 63. FC I.xvi.7 (228).

151 GF 56-7. For these knights see J. Riley-Smith, First Crusaders, p. 226 (William of Grandmesnil); p. 200 (Aubrey); p. 210 (Guy Trousseau of Montlhéry) and p. 214 (Lambert the Poor).

152 PT 97-8. For Ivo of Grandmesnil see J. Riley-Smith, First Crusaders, p. 214.

153 RA 256 (284):... admodum pauci remansissent.

154 RA 256 (284).

155 FC I.xx.2 (246).

156 AA iv.37 (307).

157 AA iv.39 (309).

158 RM 782.

159 GN 217; GF 56. 
phenomenon of knights slipping away by rope was sufficiently widespread that it came to the attention of the Byzantine historian Anna Comnena and by the time that Orderic Vitalis wrote his Ecclesiastical History (1123-1141) these escapees were being known by the mocking sobriquet 'rope-dancers.' ${ }^{160}$

Under these circumstances several visionaries came forward, two of whom were very explicitly connected to the pauperes of the Christian forces and both with a similar message, that God would aid the Christians if they sought battle with Kerbogha.

Stephen of Valence was a priest, ${ }^{161}$ 'a man most worthy of credit and of good life. ${ }^{162} \mathrm{He}$ mounted the hill in Antioch, to where there was a gathering of the princes near the citadel, and reported his vision. Stephen said that he had taken refuge in the Church of St Mary in a fearful state of mind. Christ had appeared to him and, although expressing anger at the lust of the Christians following the fall of Antioch, Christ had relented following the intervention of Our Lady and St Peter. The Lord promised that if they sung Congregati sunt (Psalm 47:5) in the daily Office he would return within five days with a mighty help. ${ }^{163} \mathrm{In}$ an addition to the text of the Gesta Francorum, Peter Tudebode, present in Antioch at the time, put in an extra line of oratio recta, reporting that Christ ordered everyone to accept penance and with bare feet make procession through the churches and give alms to the pauperes. ${ }^{164}$

This is useful additional information that the vision of Stephen was giving expression to the needs of the poor. The vision of Stephen was rooted in an orthodox theology and practice of the clergy. He offered to throw himself from a tower to prove the truth of his words, but Adhémar, who instead had the priest swear on the Gospels and a crucifix, rejected this. ${ }^{165}$ As a result of this vision the princes assembled and took an oath. According to the Gesta Francorum the oath was that they would not flee so long as they lived. Raymond of Aguilers's version had the qualification, 'unless by the common counsel of all,' testifying to the low morale among even the most determined of the princely leaders of the crusade. ${ }^{166}$ In either case, as the news of the oath spread

\footnotetext{
160 AC xi.6 (348); OV 6, 18.

161 GF 57; RA 236 (282): sacerdos.

162 RA 236: ...vir magni testimonii, et bonae vitae.

163 GF 57-8.

164 PT 100.

165 GF 58.

166 GF 59, RA 107 (256):... nisi de communi consilio omnium.
} 
it greatly encouraged the broader body of Christians. Guibert of Nogent elaborated on the terse account in the Gesta Francorum to make it clear that it was the minores, the lower social order, who rejoiced on the news of the oath taking. ${ }^{167}$

A second visionary who came forward at this time was Peter Bartholomew, the discoverer of the much-debated relic, the Holy Lance. Peter Bartholomew was the servant of William Peyre of Cunhlat, from the Provençal region of France. ${ }^{168}$ Raymond of Aguilers introduced Peter as, 'a certain pauper rusticus. ${ }^{169}$ He reported Peter as being hesitant to approach the princes, recognising his paupertas. ${ }^{170}$ Similarly Peter claimed to have been, standing in fear from his paupertas. ${ }^{171}$ Peter emphasised his paupertas twice more, the second time indicating that he was among those of the expedition who were starving at the siege of Antioch, telling the princes that having reflected again on the weakness of his paupertas he feared that if he came forward they would proclaim him a famished man who invented the visions to obtain food. ${ }^{172}$ As discussed in Chapter One, the language of Raymond's history at in this account has echoes of the Vulgate and particularly of Ecclesiasticus, where it is stated that no matter how lowly a person, God can raise them up. ${ }^{173}$

In general, Raymond of Aguilers, had a very different view of the pauperes from the other early crusading sources. For him they were not a burden, nor dissolute or foolish, but rather they were particularly suited to the expedition, with its echoes of the journey of the Children of Israel. Peter Bartholomew in particular fitted Raymond's notions that poverty was no barrier to being close to God. According to Raymond, it was precisely this point that was at issue in the credibility of Peter Bartholomew as a visionary. Those who disbelieved Peter drew attention to his low social state. 'Certain people began to say that they would never believe that this man was spoken to by God, and He would desert princes and bishops to be revealing Himself to a rusticus homo. ${ }^{174}$

${ }^{167}$ GN 221.

${ }_{168}$ For Peter Bartholomew see J. Riley-Smith, The First Crusaders, p. 216.

169 RA 88-9 (253):... pauperem quemdam rusticum.

${ }_{170}^{170}$ RA 95 (254).

171 RA 96 (254).

172 RA 97 (255).

${ }^{173}$ See above pp. 33-4.

${ }^{174}$ RA 229-30 (280-1): coeperunt quidam dicere, quod numquam crederent quod huiscemodi homini loqueretur Deus et dimitteret principes et episcopos et ostenderet se rustico homini. 
Peter Bartholomew had a certain level of knowledge of Scripture and church Offices. ${ }^{175}$ Although a servant, he was also a combatant, as he was on foot in a skirmish between the arriving forces of Kerbogha and the garrison of Antioch, 10 June 1098, where, trapped between two knights, he was nearly crushed to death in the retreat through the city gates. ${ }^{176}$

The other sources, especially those dependent on the Gesta Francorum, were unable to define the social status of the visionary, as for them Peter Bartholomew was described very vaguely as 'a certain man' or 'a certain pilgrim. ${ }^{177}$ The descriptions provided by Raymond of Aguilers are therefore crucial, particularly as the chaplain was given responsibility for Peter after the visionary came forward and they shared a tent together. ${ }^{178}$ From Raymond's account and his report of the views of the enemies of the visionary it is clear that Peter was a youth of very lowly social status.

It is understandable then that Peter Bartholomew should initially approach the senior princes in a very deferential and cautious manner. For someone of his status to confront the princes of the expedition over its direction was a challenge that under other circumstances would have been very dangerous. Peter Bartholomew returned from several wide ranging foraging expeditions to seek a meeting with the papal legate, Bishop Adhémar of Le Puy, Count Raymond of Toulouse and Peter Raymond of Hautpoul, one of the Count's leading vassals. ${ }^{179}$ This company was from his home territory and, at least, could understand him. The peasant visionary claimed that St Andrew had appeared to him during the night and that this was the fifth such visitation.

After a lengthy and apologetic recounting of the circumstances that obliged such a lowly person as himself to approach the princes, Peter came to the point. He declared that he had a tangible proof of divine aid, the Lord's Lance, whose hiding place was revealed to him by St Andrew. ${ }^{180}$ St Andrew was the predominant figure in the visions of Peter Bartholomew. J. Riley-Smith suggested that being the patron of Constantinople in its resistance to Petrine ecclesiology, St Andrew would

175 RA 113-14 (257-8).

176 RA 89 (253).

177 GF 59: Quidam peregrinus. FC I.xviii. 1 (235): Quodam homine. BD 67: Quidam peregrinus. GN 221: Cuidam de exercitu. RM 822: Quidam peregrinus.

178 RA 100 (257).

179 RA 254 (284). For Peter Raymond of Hautpoul see J. Riley-Smith, First Crusaders, p. 217 .

180 RA 94 (254). 
have been seen to be more exotic and appropriate to the fact that the crusaders found themselves in a foreign region. ${ }^{181}$ This issue might well have influenced the visions of Peter Bartholomew. Although there was a church dedicated to St Andrew in Antioch at the time of the First Crusade, ${ }^{182}$ it would have been extremely undiplomatic to come before a legate of the Gregorian papacy with the news that the lance that had pierced Christ's side had been hidden there, rather than in the church of St Peter. As it was, Adhémar was extremely sceptical of the news brought by Peter Bartholomew, not least because, as Stephen Runciman has shown, the legate would have been aware of Constantinople's much more convincing claims to house the same lance. ${ }^{183}$

One of the themes of the visions of Peter Bartholomew was that God had allocated a special role in the expedition to Count Raymond of Toulouse. ${ }^{184}$ This bid for the patronage of the elderly and devout count was entirely successful and Peter Bartholomew was taken into the care of his chaplaincy. ${ }^{185}$

On 13 June 1098 a meteorite fell in the direction of the camp of Kerbogha, giving material for the clergy to give further encouragement to the Christian forces. ${ }^{186}$ The following day digging began in the Church of St Peter in order to unearth the Holy Lance. Initially Count Raymond of Saint-Giles himself along with his more powerful vassals, having locked out all others, undertook the work. But by evening they were overcome with tiredness. A note of doubt and inconsistency enters the description of events by Raymond of Aguilers, himself a member of the first party of workers. St Andrew had been described by Peter as having placed the Lance in the ground while the visionary was watching, implying that it was close to the surface; but the initial twelve men must had dug a great deal deeper than they would have been led to expect and indeed 'by evening some had given up hope of unearthing the Lance. ${ }^{187}$ Fresh workers dug furiously until they too became tired. At this point Peter dropped into the deep hole and urged everyone to pray at length. Raymond's account is honest enough to convey a certain

\footnotetext{
${ }^{181}$ J. Riley-Smith, The First Crusade, pp. 105-6.

182 AA vi.30 (376).

183 S. Runciman. 'The Holy Lance Found at Antioch', Analecta Bollandiana 68 (1950), pp. 197-205.

${ }^{184}$ RA 93 (254).

185 RA 100 (255).

186 RA 257 (285); GF 62.

187 RA 257 (285): In vespere desperare quidam de inventione lanceae coeperunt.
} 
lack of conviction in his description that while everyone else present was above the pit, praying, Peter alone discovered the Lance. ${ }^{188}$

Those who had less of an interest in promoting the leading role of Count Raymond were quick to dispute the legitimacy of the relic. Fulcher of Chartres reported that the allegation made against Peter Bartholomew by many of the clergy and the people was that it 'was not the Lord's Lance, but it was another one deceitfully contrived by that stupid man. ${ }^{189}$ Guibert of Nogent, a defender of the Holy Lance, wrote that later the vulgus began to challenge Peter Bartholomew for staging the discovery and exhibiting an ordinary lance. ${ }^{190}$ Ralph of Caen, the author of the Gesta Tancredi, wrote that Peter Bartholomew was a 'versatile fabricator of lies'. ${ }^{191}$ Ralph described the finding of the Lance as a deception involving the planting of an Arabic spear point. Ralph was not present on the First Crusade. He wrote his near panegyrical metrical work between 1112 and 1118, but he had served with Bohemond and Tancred. More importantly for Ralph's sources with regard to Peter Bartholomew, Arnulf of Chocques, chaplain to Duke Robert of Normandy on the First Crusade and Patriarch of Jerusalem from 1112, whom he visited before writing his history, taught him and helped shape the work. It was Arnulf who led the challenge that resulted in the death of Peter Bartholomew. ${ }^{192}$ Not only did Ralph record the grounds on which the legitimacy of the Lance was challenged: he also saw the whole issue in decidedly political terms. Those in favour of the Lance were Count Raymond and the Provençals; those against were Normans led by Bohemond. ${ }^{193}$

Unsurprisingly, equal scepticism was evident in the version of events that subsequently circulated in the Arab world. Ibn al-Athīr (1160-1233) wrote that: 'there was a monk there, of influence among them, who was a cunning man. He said to them, "the Messiah (blessings be upon Him) had a lance which was buried in the church at Antioch, which

\footnotetext{
${ }^{188}$ RA 203 (276).

189 FC I.xviii.3 (237-8):... contigit multos de clero ac populo haesitare, quod non esset illa dominica Lancea, sed ab homine illo stolido altera erat fallaciter inventa.

${ }^{190}$ GN 262 (286).

191 RC 676: versutus mendaciique commentor.

192 For Arnulf, chaplain to Robert I, duke of Normandy before becoming patriarch of Jerusalem in 1099 and again from 1112 to 1115 . See R. Foreville, 'Un chef de la première croisade: Arnulf Malecouronne,' Bulletin Philologique et Historique du Comité des Travaux Historiques et Scientifiques (1953-4), pp. 377-90. See also B. Hamilton, The Latin Church in the Crusader States (London, 1980), pp. 12-13.

193 RC 678.
} 
was a great building. If you find it, you will prevail, but if you do not find it, then destruction is assured." He had previously buried a lance in a place there and removed the traces [of his digging]. ${ }^{194}$

At the time, however, as several modern historians have noted, all the crusading princes united behind the Lance. ${ }^{195}$ This is evident from the view of the Gesta Francorum, which, while generally being positively disposed towards Bohemond, whose faction later became the greatest critics of the Lance, wrote of the discovery of the Lance that it was found as had been foretold by Peter Bartholomew with subsequent boundless rejoicing. ${ }^{196}$ A letter to Pope Urban II of the united princes, headed by Bohemond, also referred favourably to the Lance, reporting that through its discovery and many other divine revelations they were much strengthened and more willing to do battle. ${ }^{197}$

In his account of the finding of the Holy Lance, Robert the Monk wrote that once it had been unearthed all swore that they would not give up the journey and so all the plebeia multitudo rejoiced, that the maiores had sworn this oath. ${ }^{198}$ This oath taking, as has been noted, was attested to by other sources but was described as arising from the vision of Stephen of Valence rather than the discovery of the Holy Lance. Robert's version of events does, however, convey his understanding that a tension existed between the upper and lower social orders over the question of flight from Antioch, as well as contain the interesting phrase for the lower class, the plebeia multitudo.

In addition to the two major visions, the crisis of the crusade produced several others. Albert of Aachen reports how a Lombard cleric brought great comfort to all by recounting how at the outset of the expedition, an Italian priest had met the fourth century Church Father, Bishop Ambrose of Milan. The saint had promised that after many hardships the Christians would conquer Jerusalem. Those that died on

${ }^{194}$ Ibn al-Athīr, al-Kamil fi'l-ta'rikh, Part 1, trans. D. S. Richards (Aldershot, 2006), p. 16.

${ }^{195}$ C. Morris, 'Policy and Visions - The case of the Holy Lance at Antioch' War and Government in the Middle Ages, ed. J. Gillingham and J. C. Holt (Woodbridge, 1984), p. 36; J. France, Victory in the East, pp. 278-9.

${ }_{196}$ GF 65.

${ }^{197}$ Letter of Bohemond and the other princes to Pope Urban II: Hagenmeyer, Epistulae et Chartae, p. 163

198 RM 823. 
the way, providing they had been abstinent, would be crowned joyfully in heaven. ${ }^{199}$

The chronicler Fulcher of Chartres, not an eyewitness at this point, being with Baldwin's contingent in Edessa, nevertheless reported a further vision of which he was subsequently informed and which he described as being typical of many. A fleeing Christian descended by ropes from the walls of Antioch only to meet the apparition of his dead brother, who told him not to flee because the Lord would be with the Christians in battle. ${ }^{200}$ It is extraordinary how consistent was the issue addressed in the cluster of visions that took place at this time of crisis. In each case they were a response to the threat of the disintegration of the movement. In the case of the visions of Stephen, Peter and that reported by Fulcher, they were also a direct appeal for battle with Kerbogha.

The commoners were revitalised by the oath of the senior princes and the apparent signs of divine favour. They now began to agitate that the princes should go further and initiate battle without delay. Raymond of Aguilers wrote that the vulgus, despite having recently been consumed by famine and fear, now criticised the princes, questioning the reason for the delay in the battle. ${ }^{201}$ The historian Archbishop William of Tyre, writing some seventy years after these events, but with eyewitness accounts before him, including now lost material, and with access to an oral tradition about the First Crusade, echoed this observation. William wrote that 'the common people, aflame with desire, accused the princes of inactivity and criticised their delays. ${ }^{202}$

The princes responded by sending an envoy to negotiate with Kerbogha. Their striking choice to conduct the embassy was Peter the Hermit, the main leader of the People's Crusade. This was particularly surprising as it was claimed in the Gesta Francorum, that during the difficult winter siege of Antioch, 20 January 1098, Peter the Hermit had attempted to abandon the crusade, in the company of William Carpenter, only to be hauled back by Tancred. ${ }^{203}$ Jean Flori has discussed this passage and disputes its veracity, suggesting that the appearance of Peter the Hermit's name in the text was a later addition

199 AA iv.38 (307-9).

200 FC I.xx.1 (244-7).

${ }^{201}$ RA 259 (285).

${ }^{202}$ WT 6.15 (326): populares, eodem succensi desiderio, principum arguebant desidiam et moras increpabant.

${ }^{203}$ GF 33. See H. Hagenmeyer, Chronologie de la Première Croisade 1094-1100, (Hildesheim, 1973), p. 122. For William Carpenter see J. Riley-Smith, The First Crusaders, p. 226 . 
by someone hostile to the anarchic and subversive people represented by the itinerant preacher. ${ }^{204}$

The idea that Peter the Hermit left the crusade is not present in any of the sources outside the Gesta Francorum tradition and particularly important here is Tancred's biographer, Ralph of Caen, who while providing the information that as a punishment and public display of his ignominy, William's tent was made into a latrine, says nothing about Peter the Hermit or Tancred's role in bringing him back to the siege of Antioch. Moreover, Ralph reported that it was Guy II, count of Rochfort, 'the Red', seneschal of the king of France, who was William's companion in trying to flee. ${ }^{205}$ Flori points out that since the Gesta Francorum was promoted in France around the year 1105, in support of a recruiting drive for Bohemond, the Norman prince would not have wanted to risk the enmity of the royal entourage and the now popular hero, Guy, by drawing attention to the fact that he had tried to flee the siege of Antioch. Therefore, offers Flori, Guy's name was deleted and Peter the Hermit's name inserted at this point. ${ }^{206}$ Even if Peter the Hermit had deserted the crusade in January, he must have very quickly regained lost ground to be selected for such an important mission by June.

The negotiations between Peter the Hermit and the Turkish atabeg provided dramatists with a great moment. Those parts of the Gesta Francorum that read most like a chanson take place here and in the preceding discussion between Kerbogha and his mother. The opportunity for placing a proud defence of Christianity into the speech of Peter and a hubristic reply into that of Kerbogha undoubtedly distorts the report of this mission in the Gesta Francorum and those writings dependent on it. It is valuable therefore, that John France has drawn attention to the version of the embassy in a source belonging to a different tradition, the Historia Iherosolimitana of Albert of Aachen. ${ }^{207}$

According to Albert, the city was offered to Kerbogha and the senior princes were willing to serve under him, providing that he become a Christian; failing this, a combat of twenty champions was offered. ${ }^{208}$

\footnotetext{
${ }^{204}$ J. Flori, Pierre L'Ermite, pp. 482-92.

205 RC 650. For Guy II, count of Rochfort, 'the Red', see J. Riley-Smith, The First Crusaders, p. 209.

${ }^{206}$ Ibid., p. 490.

${ }^{207} \mathrm{~J}$. France, Victory in the East, p. 280.

208 AA iv.44 (316-8).
} 
This latter part of the embassy, the offer of a trial by combat, is confirmed by the accounts of the incident in Raymond of Aguilers and Fulcher of Chartres. ${ }^{209}$ France, however, found the former aspect of Albert's report, the idea that the princes offered to convert and become vassals of the atabeg, difficult to take seriously and conjectures that it might have reflected Albert's sources, who were ordinary crusaders, suspicious at this point of the senior princes. ${ }^{210}$ Certainly, if the Christian princes seriously intended to come to an understanding with Kerbogha they picked an unlikely conduit for the negotiations. Peter the Hermit was not one of their class and had a special association with the pauperes on the First Crusade, for example, as the main person responsible for the distribution of tithes to the poor after Adhémar's death. ${ }^{211}$ It seems possible, in fact, given the agitation of the poor in favour of battle that formed the background to this embassy, that Peter the Hermit was chosen precisely because of the mistrust shown by the pauperes towards the princes.

In an interesting amendment to a line in the Gesta Francorum Peter Tudebode altered Peter's speech to Kerbogha from reading 'our maiores' say that you should quickly withdraw ${ }^{212}$ to 'our maiores sive minores' say that you should quickly withdraw. ${ }^{213}$ Peter Tudebode generally followed the Gesta Francorum word for word, so although the alteration is slight, it might well reflect the fact that Peter Tudebode wanted to make clear that Peter the Hermit was speaking not just on behalf of the maiores but everyone trapped in the city.

Naturally, given the strength of his position and the opportunity to become ruler of Antioch, something that would not have previously have been a possibility for him, Kerbogha rejected the embassy. He would accept surrender by the Christians and made some kind of offer to give land and castles to the leaders. ${ }^{214}$ Peter returned and the Christians prepared for battle by distributing alms to the poor, fasting and conducting religious services.

The battle of 28 June 1098 was the turning point of the entire crusade. As the Christians set out in a series of contingents, approxi-

\footnotetext{
${ }^{209}$ AA iv.45 (318); RA 127; FC I.xxi.1 (247-8).

${ }^{210}$ J. France, Victory in the East, p. 280.

211 RA 214-5 (278).

212 GF 66.

${ }^{213}$ PT 108.

${ }^{214}$ See below pp. 181-2.
} 
mately based on region, their enemies in the citadel of city, high up the mountainside, waved a black flag to alert Kerbogha. ${ }^{215}$ The atabeg of Mosul allowed the full body of Christian forces to emerge, much to their relief. In Raymond of Aguilers's history this is explained by Kerbogha's complacency, which was so great that he continued to play chess as they advanced. ${ }^{216}$ A more likely explanation for his decision is that the Muslim leader wished to employ their traditional tactic of letting the enemy move forward, while light cavalry encircled them. ${ }^{217}$

The main battlefront would have looked bleak for the crusaders. They were desperately short of horses, Albert of Aachen says there were only 150-200 horses available for the battle. Matters were so bad that some knights rode to the conflict on donkeys. ${ }^{218}$ By contrast Kerbogha was at the head of an enormous army, with troops drawn from across the Seljuk world. The very size of the Muslim army, however, was to count against it. For the political fault lines it contained were deep. In particular Duqāq of Damascus probably estimated it was more dangerous to his rule if Kerbogha were victorious and Mosul united with Antioch, than for the Christians to win. Other Muslim rulers, such as Janāh ad-Daulah of Homs, had fears for their future in the event of Kerbogha being victorious. ${ }^{219}$

A direct and swift assault by the Christian forces caught the vast Muslim army in a state of dispersal and opened up the political fault lines. Duqāq took his troops from the field and the rest of the Muslim cavalry soon followed, leaving their infantry to be destroyed and their camp to be overrun, with Kerbogha's own tent a prize of battle. From the Christian perspective it was an astonishing victory with very few casualties. More than astonishing, it was a miracle. The Holy Lance had been carried into the battle by Raymond of Aguilers, who felt that it had protected him. ${ }^{220}$ The author of the Gesta Francorum recorded the fact that some of his fellow knights had seen celestial warriors, SS George, Demetrius and Mercurius, lead a charge. ${ }^{221}$ Above all, the rejoicing Christian poor celebrated those whose visions had promised

\footnotetext{
${ }^{215}$ AA iv.48 (324).

${ }^{216}$ RA 125; see also FC I.xxii.5 (253); RC 667.

217 For this battle see J. France, Victory in the East, pp. 269-296.

218 AA iv.54 (332).

${ }^{219}$ Ibn al-Athīr, al-Kamil fi'l-ta'rikh, pp. 16-7; Kemal al-Din, Extraits de la Chronique d'Alep, RHC Or. 3, 577-690, here 582-3.

${ }^{220}$ RA 263 (286).

${ }^{221}$ GF 69.
} 
victory and whose promises had come true in such a spectacular fashion. The standing of Peter Bartholomew in particular now soared, to bring this lowly servant to a position of great authority. 